\title{
Pola Penggunaan Sapaan Bahasa Bima
}

\section{Pattern Of Use Of Bima Language Greetings}

\author{
Hasan \\ Universitas Hasanuddin \\ hasanali.unhas23@gmail.com
}

\begin{abstract}
Abstrak
Artikel ini merupakan hasil penelitian yang dilakukan di Lembaga Penelitian Universitas Hasanuddin. Permasalahan yang diteliti adalah bagaimana pola-pola penggunaan sapaan dalam bahasa Bima.Tujuannya adalah mencari dan menemukan variasi pola penggunaan sapaan dalam bahasa Bima. Pengumpulan data dilakukan melalui penelitian lapangan atau kerja medan dengan teknik: (1) observasi (pengamatan), (2) wawancara, (3) rekaman, (4) catat, (5) pilah. Data dianalisis dengan metode deskriptif kualitatif. Hasil penelitian menunjukkan bahwa, variasi jenis dan pola penggunaan sapaan bahasa Bima dapat diklasifikan sebagai berikut: (1) sapaan kata ganti diri, yang terdiri atas: (a) sapaan persona pertama (tunggal dan jamak), (b) sapaan persona kedua (tunggal dan jamak), (c) sapaan persona ketiga (tunggal dan jamak); (2) sapaaan nama diri, yang terdiri atas: (a) menyapa dengan nama diri asli (nama yang sebenarnya), (b) menyapa dengan nama diri secara sopan (penghormatan); (3) menyapa secara keakraban; (4) sapaan berupa jabatan dan gelar, yang terdiri atas: (a) sapaan berupa jabatan, (b) sapaan berupa gelar, (c) sapaan berupa gelar khusus, (d) sapaan gelar khusus dengan nama diri + kata sifat.
\end{abstract}

Kata Kunci: Pola, Sapaan, Bahasa Bima

\begin{abstract}
This article is the result of research conducted in 2012 (Lembaga Penelitian Universitas Hasanuddin). The problem investigated in this study was how the patterns of greeting use in Bima. The aim was to look for and find the variations / types of greeting usage pattern in Bima. Data collection was done through field research or field work using the following techniques: (1) observation (surveillance), (2) interviews, (3) records, (4) notes, (5) sort out. Data were analyzed by descriptive method.The results showed that variations in types and patterns of use of Bima language greetings can be classified as follows: (1) selfpronouns, which consist of: (a) first-person greeting (singular and plural), (b) secondperson greeting (single and plural), (c) third-person greeting (singular and plural); (2) selfname greetings, consisting of: (a) greeting with the original self-name (real name), (b) greeting with a polite self-name (respect); (3) greeting familiarly; (4) greetings in the form of positions and titles, consisting of: (a) greetings in the form of positions, (b) greetings in the form of titles, (c) greetings in the form of special titles, (d) greetings in special titles with self-names + adjectives.
\end{abstract}

Keywords: Pattern, Greeting, Bima Language 


\section{Pendahuluan}

Bahasa Bima adalah salah satu bahasa daerah yang hidup, tumbuh, dan berkembang di wilayah nusantara. Bahasa Bima dipakai oleh masyarakat pendukungnya yang secara administratif dan geografis mendiami wilayah tengah dan timur Pulau Sumbawa (Kabupaten Dompu dan Kabupaten Bima) yang merupakan bagian wilayah Propinsi Nusa Tenggara Barat. Bahasa Bima juga dipakai oleh masayarakat Bima dan Dompu yang merantau ke daerah-daerah lain (termasuk di Makassar). Dilihat dari segi jumlah penuturnya, bahasa Bima berada di kelompok "B" yaitu kelompok bahasa yang jumlah penuturnya antara 100 ribu sampai dengan 1 juta orang. Jumlah penutur bahasa Bima tepatnya 365.000 orang (Parera, 1991).

Secara historis masayarakat penutur bahasa Bima banyak mendapat pengaruh dari suku-suku dan kerajaan lain (termasuk Kerajaan Gowa) yang dengan sendirinya cukup berpengaruh terhadap pemakaian bahasanya. Adanya suku-suku lain yang mendiami wilayah pemakaian bahasa Bima, termasuk pengaruh bahasa Indonesia membawa dampak terjadinya variasi pemakaian bahasa, termasuk variasi pemakaian bentuk sapaan dalam bahasa Bima. Hal ini memberikan warna tersendiri dalam bertutur sapa anggota masyarakatnya. Misalnya, seorang anak menyapa bapaknya dengan bentuk sapaan : ama, aba, baba, dae, uba, abu, aji, bapa, atau papa. Di sisi lain, masayarakat dalam kontak komunikasi bahasa sangat memperhatikan lawan komunikasinya, dengan siapa dia berkomunikasi, dalam situasi apa dan dalam konteks apa berkomunikasi itu dilakukan. Hal ini menyebabkan terjadinya variasi penggunaan bentuk sapaan dalam bahasa Bima.

Bahasa Bima sebagai bahasa pergaulan dituntut pula oleh keadaan untuk dipergunakan sesuai dengan fungsinya sebagai sarana komunikasi sosial kemasyarakatan, sebagai sarana komunikasi sosial dalam kehidupan bermasyarakat. Bahasa Bima juga sebagai alat pengungkapan penghormatan. Masyarakat Bima dalam bertutur sapa tidak pernah lepas dari penggunaan ungkapan-ungkapan untuk memuliakan atau menghormati seseorang. Dengan demikian, kesopanan berbahasa dalam pergaulan bagi masyarakat Bima merupakan ciri masyarakat yang beradab, sebagaimana diungkapkan oleh Gazalba (1978:98) bahwa bahasa juga merupakan adabiah masyarakat, dan masyarakat adabiah suatu bangsa.

Gambaran tentang variasi penggunaan bentuk sapaan seperti yang diuraikan di atas, merangsang dan memotivasi penulis untuk mengangkat topik "Bentuk-bentuk Sapaan dalam Bahasa Bima". Pokok permasalahan yang dikaji lebih lanjut adalah jenis/ragam bentuk sapaan yang dikaitkan dengan variasi pola penggunaannya berdasarkan status/stratifikasi social, usia, jenis kelamin, situasi penggunaannya, dan lain-lain.

\section{Landasan Teori}

Penggunaan sapaan merupakan ungkapan perasaan penyapa kepada pesapanya. Ayatrohaedi (1980:64) menyatakan bahwa suatu sapaan dengan ungkapan-ungkapan sopaan merupakan alat yang dapat memindahkan suatu konsep dari komunikator kepada komunikan secara kompleks melalui alat bicara atau artikulator. Pada bagian lain Ayathrohaedi menyatakan bahwa, sapaan itu bersumber dari ide, pikiran, curahan hati, dan rasa hormat atau semacamnya untuk dipindahkan dari dalam persemaiannya kepada yang ditujukannya. Hal ini berarti bahwa penggunaan sapaan dalam interaksi anggota 
suatu masyarakat merupakan cerminan suatu masyarakat yang memperhatikan sopan santun dan tatakrama dalam pergaulan hidupnya sehari-hari.

Sapaan sopaan atau sapaan halus juga merupakan manifestasi dari penyapa untuk menyatakan kehendak, pikiran, dan perasaan, serta pandangannya dalam bentuk-bentuk suatu bahasa yang dianggap paling tepat. Sapaan atau ungkapan sopan lahir karena adanya keinginan kita untuk berkenalan atau menghormati orang lain. Percakapan dengan satuan bahasa yang disebut sapaan sopan dapat diukur dengan menggunakan parameter. Pemahaman terhadap konteks budaya akan memungkinkan seorang pelajar bahasa asing untuk menghasilkan tuturan-tuturan yang bukan saja benar secara gramatikal, melainkan juga tepat untuk situasi tertentu (Roselani, 1991).

Lech (lihat Pei, 1979: 158) mengemukakan bahwa parameter yang digunakan sebagai ukuran sapaan, yang memungkinkan interlokutor dapat saling mengerti dan mengetahui ungkapan mana, untuk siapa, kapan, dan di mana itu wajar dipakai dalam suatu interaksi. Dengan parameter itulah penyapa dan tersapa dapat saling mengerti situasi dan peringkatnya. Setiap sapaan dan dialog bagi seseorang yang berstatus sosial menengah atau di atasnya, dimulai dengan melihat situasi dan status sosial suatu masyarakat tempat dia berada, sesuai dengan pandangan dan pengalaman hidupnya. Sikap demikian akan membawa suasana keakraban, menghilangkan rasa curiga dan rendah diri bagi tersapa.

Menurut (Gusnawaty, 2013), pola sapaan bermakna menghormati pendengar dengan cara yang tidak berlebihan. Adapun menurut (Menjamin, 2018), sapaan adalah sebuah bentuk dalam pemakaiannya untuk awal berkomunikasi, berinteraksi dengan sesama penutur dan bentuk yang digunakan untuk menyapa seseorang, cara untuk menghormati kepada sesama agar lebih akrab dan dikaitkan dengan norma dan budaya dalam masyarakat. Sistem sapaan yang digunakan di dalam masyarakat berbeda tergantung pada budaya lokal. Istilah ini dikenal dengan address terms.

Bahasa dipergunakan di tengah-tengah masyarakat sebagai alat komunikasi yang kompleks karena berbagai fenomena penggunaan bahasa dapat kita jumpai dalam berbagai aktivitas manusia. Misalnya seseorang yang menggunakan bahasa secara berbeda, itu tergantung pada latar belakangnya sehingga seringkali ada penyimpulan bahwa ada korelasi antara aspek-aspek ujaran seseorang dengan tempat kelahirannya atau tempat ia dibesarkan, pendidikannya, kelompok sosialnya, atau bahkan pekerjaannya. (Hasyim, 2008).

\section{Metode Penelitian}

Penelitian ini menggunakan metode deskriptif. Pengumpulan data dalam penelitian ini dilakukan melalui penelitian lapangan atau kerja medan. Operasional cara kerja lapangan digunakan beberapa teknik : (1) teknik observasi (pengamatan), yaitu mengamati secara langsung fenomena penggunaan bentuk-bentuk sapaan oleh penutur bahasa Bima pada lokasi penelitian yang telah ditetapkan; (2) teknik wawancara, yaitu mengajukan pertanyaan-pertanyaan secara tebuka dan terstruktur, serta terencana kepada responden sehingga memudahkan perbandingan antara satu data dengan data lain secara lancar dan tepat; (3) teknik rekam, perekaman terhadap semua data yang diberikan oleh para informan, baik melalui percakapan langsung (perekaman spontan) maupun melalui wawancara (perekaman pilihan); (4) teknik catat, yaitu melakukan transkripsi atas semua data yang diperoleh dari informan; (5) teknik pilah untuk menentukan data yang benar-benar dibutuhkan, dalam hal ini memilah-milah jenis sapaan dengan berbagai variasinya sehingga jelas kedudukannya pada masing-masing kelompok. 
Populasi dalam penelitian ini adalah semua bentuk sapaan yang dipakai oleh masyarakat penutur bahasa Bima pada umumnya, sedangkan sampel penelitian adalah bentuk sapaan yang digunakan masyarakat penutur asli bahasa Bima dengan berbagai pola dan variasinya. Penutur asli bahasa Bima yang dijadikan responden seluruhnya berjumlah 60 orang yang ditentukan berdasarkan jenis kelamin, umur, pendidikan, profesi, dan stratafikasi sosial. Karena penulis penutur asli bahasa Bima maka penulis dapat melakukan formulasi data secara kreatif. Penelitian dilakukan di tiga lokasi di Kabupaten Bima, yaitu Kecamatan Rasana'e, Kecamatan Sape, dan Kecamatan Bolo. Kecamatan Rasana'e berada di ibu kota kabupaten, sedangkan Kecamatan Sape dan Kecamatan Bolo di luar ibu kota kabupaten.

Data dianalisis dengan metode deskriptif. Metode deskriptif ialah penelitian yang dilakukan semata-mata hanya berdasarkan pada fakta yang ada atau fenomena yang memang secara empirik, sehingga yang dihasilakan dapat dikatakan sifatnya seperti potret; paparan apa adanya (Sudaryanto, 1988:62). Jadi, analisis yang dilakukan dalam penelitian ini yaitu penggambaran atau pemerian tentang penggunaan bentuk-bentuk sapaan dengan berbagai variasinya sebagaimana yang digunakan oleh penutur asli bahasa Bima.

\section{Hasil}

Analisis data disajikan dengan kaidah-kaidah yang meliputi keterkaitan bentuk sapaan dengan variasi-variasi yang berdasarkan jenis kelamin, umur, profesi, status sosial, dan situasi penggunaannya.

\section{Variasi Pola Penggunaan Bentuk Sapaan}

Jenis/ragam bentuk sapaan asli bahasa Bima dapat dilakukan sebagai berikut.

\section{Sapaan berupa kata ganti diri (persona), terdiri atas:}

a. Sapaan persona pertama (tunggal dan jamak)

Seperti : nahu/ndaiku 'saya' atau aku (tunggal), mada 'saya' (bentuk halus/sopan), nami 'kami' (jamak), mada doho 'kami' (bentuk halus/sopan), ndai 'kita' (jamak).

Bentuk sapaan persona pertama nahu 'saya' (tunggal) dan nami 'kami' (jamak) dipakai apabila penyapa lebih tua atau sama usianya dengan pesapa, sedangkan bentuk sapaan ndaiku 'saya' dan mada doho 'kami' (bentuk halus/sopan) dipakai apabila penyapa seumur atau sederajat jarak/status sosialnya dengan pesapa. Atau dapat juga dipakai kepada orang yang baru dikenal (belum akrab). Selanjutnya bentuk sapaan mada 'saya' (bentuk halus/sopan) dipakai apabila penyapa lebih muda usianya dari pesapa.

\section{b. Sapaan persona kedua (tunggal dan jamak)}

Seperti :nggomi 'kamu' atau engkau (tunggal), nggomi doho 'kalian/kamu sekalian (jamak), ndaimu 'anda (netral), ita 'anda/tuan (bentuk halus/sopan), ita doho 'anda/tuan sekalian (jamak bentuyk halus/sopan).

Bentuk sapaan persona kedua nggomi 'kamu/engkau' (tunggal) dan nggomi doho 'kalian/kamu sekalian (jamak) dipakai apabila penyapa lebih muda usia atau sederajat dengan pesapa. Selanjutnya, bentuk sapaan ndaimu 'Anda/tuan' (tunggal) dan ita doho 'Anda/tuan sekalian' (jamak) dipakai apabila penyapa lebih muda usia/status sosialnya daripada pesapa. Baik ita maupun ita doho merupakan bentuk halus/sopan sebagai bentuk sapaan penghormatan. 


\section{c. Sapaan persona ketiga (tunggal dan jamak)}

Seperti :sia 'dia/ia; (tunggal), sia doho 'mereka' (jamak)

Bentuk sapaan persona ketiga sia 'dia/ia' (tunggal) dan sia doho 'mereka' (jamak) dipakai apabila orang yang disapa lebih muda usianya atau sederajat dengan yang menyapa.

Contoh penggunaannya :

> Sia ede nawancuku cakana karawi. 'Dia itusangat rajin bekerja'. itu'.

$>$ Nggomi aina batu rawi sia doho aka. 'Kamu jangan ikut-ikutan perbuatan mereka

\section{Sapaan berupa nama diri}

Sapaan berupa nama diri, yaitu nama orang yang dipakai untuk menyapa yang bersangkutan, baik persona kedua maupun persona ketiga. Biasanya dipakai antara sesama teman sebaya, atau untuk menyapa yang lebih muda dan akrab.

Penggunaan sapaan berupa nama diri ada dua macam cara, yaitu :

\section{a. Menyapa dengan nama diri asli (nama yang sebenarnya)}

Seperti : Hama 'Achmad/Muhammad', Hasa 'Hasan', Mina 'Aminah'

Sebagai ciri khas bahasa Bima yaitu bahasa vokalis, artinya semua kata berakhir dengan huruf vocal. Hal yang demikian berlaku juga untuk penyebutan nama diri. Bentuk sapaan berupa nama diri asli (penyebutan nama yang sebenarnya) dipakai untuk menyapa yang bersangkutan, jika yang disapa itu lebih muda atau sederajat dengan penyapa. Sapaan ini lebih akrab terutama sesama teman akrab.

Contoh : Sakola tabe nggomi Hama? 'Sekolah di mana kamu Achmad'.

\section{b. Menyapa dengan nama diri secara penghormatan (lia kai)}

Cara penyapaan seperti ini penyebutan nama dengan mengubah bunyi vocal tertentu pada suku kata tertentu pula. Perubahan bunyi vocal itu tidak konstan (tidak tetap). Oleh sebab itu secara teoritis fonologis sukar ditelusuri. Misalnya, vocal /a/ kadang berubah menjadi /e/. /i/. atau /o/.
Contoh:
Hama /a/ $\rightarrow$
'Achmad/Muhammad'
Hasa $/ \mathrm{a} / \rightarrow$
Mina /i/,/a/ $\rightarrow$
Heso /e/
Mene /e/,/e/
Hima /i/
'Hasan'
'Aminah'

Sapaan nama diri dengan cara seperti di atas hanya dipakai untuk menyapa orang yang lebih tua sebagai bentuk penghormatan/penghargaan.

\section{Sapaan keakraban}

Penggunaan sapaan dalam lingkungan keluarga (rumah tangga) bagi masyarakat Bima adalah hal yang biasa. Hal ini mencerminkan adanya hubungan keakrabatan yang erat di antara anggota keluarga. Bentuk-bentuk sapaan keakrabatan yang dipakai oleh masyarakat Bima sebagai berikut : ama 'bapak', ina 'ibu', ompu 'kakek' (laki-laki), wa'i 'nenek' (perempuan), ori 'paman', manca 'bibi', ari 'adik', sa'e 'kakak', hera 'ipar' (lakilaki), kawalu 'ipar' (perempuan), rido 'menantu' (laki-laki/perempuan), reana 'mertua' (laki-laki/perempuan).

Bentuk sapaan ama 'bapak' dan ina 'ibu' dipakai dalam lingkungan keluarga oleh seorang anak untuk menyapa orang tuanya.

Contoh penggunaan dalam kalimat:

Ama ouba ina 'Bapak dipanggil ibu'

Sebagai sapaan biasa (tutur sapa) dalam berinteraksi anggota masyarakat, sapaan ama atau ina selalui disertai dengan nama anak sulungnya. Misalnya, anak sulungnya bernama Ismail, maka sapaan untuk bapak dan ibunya adalah Ama Sama'i 'Bapak Ismail' 
dan Ina_Sama'i 'Ibu Ismail'. Cara sapaan seperti ini dipakai apabila menyapa seseorang Bapak/Ibu yang mempunyai anak sulung yang bernama Ismail.

Bentuk sapaan ompu 'kakek' (laki-laki) dan wa'i 'nenek' (perempuan) dipakai untuk menyapa kakek dan nenek oleh cucunya. Namun, dalam bertutur sapa pergaulan sehari-hari masyarakat Bima, sapaan ompu dan wa'i secara umum dipakai untuk menyapa orang yang betul-betul sudah berusia lanjut (tua renta).

\section{Sapaan berupa jabatan dan gelar}

Bentuk sapaan berupa jabatan dan gelar dipakai untuk menyapa orang-orang yang memangku jabatan dan menyandang gelar tertentu.

\section{a. Sapaan berupa jabatan}

Seperti : Galara 'Kepala Desa/Kepala Keluraha Juru tuli 'Juru Tulis (sekretaris) Desa' Jeneli 'Camat'

Bentuk sapaan jeneli 'Camat/ Pak Camat' dipakai untuk menyapa seseorang yang menjabat sebagai camat. Sekarang ini pemakain jabatan jeneli sudah sangat terbatas, hanya dikalangan kaum tua yang awam, sedangkan dikalangan masyarakat pada umumnya menggunakan sapaan Camat/Pak Camat. Demikian juga sapaan galara dan juru $\underline{t u l i}$ sudah sangat jarang dipakai terutama di kalangan kaum muda.

\section{b. Sapaan berupa gelar}

Seperti : Lebe 'Imam', Tuan Guru 'Kiyai', Abu 'Haji' (laki-laki), Umi 'Hajja' (perempuan).

Bentuk sapaan Lebe 'Imam' misalnya, dipakai untuk menyapa seseorang yang mendapat gelar dari masyarakat sebagai tokoh/ pemuka agama (Islam). Demikian juga Tuan Guru 'kiyai'. Sedangkan sapaan $A b u$ 'haji' dan Umi 'hajja' dipakai apabila seseorang yang sudah melaksanakan ibadah haji di Mekkah.

Sapaan gelar Lebe selalu diikuti oleh nama orang atau tempat wilayah operasionalnya atau kata sifat. Misalnya, Lebe Brahi 'Imam Ibrahim', Lebe Rabangodu 'Imam Kelurahan Rabangodu', atau Lebe Na'e 'Imam Besar'. Demikian juga sapaan Abu atau Umi selalu diikuti oleh nama orang untuk laki-laki yang sudah bekeluarga dan sudah mempunyai anak, maka nama anak sulungnya yang melekat dengan gelar tersebut. Misalnya, seseorang yang sudah melaksanakan ibadah haji dan mempunyai anak (sulung) yang bernama Hama 'Achmad', maka orang tersebut disapa Abu Hama 'haji Achmad'. Tetapi seseorang perempuan yang sudah melaksanakan ibadah haji nama yang melekat dengan gelar itu adalah namanya sendiri, walaupun dia sudah berkeluarga dan sudah mempunyai anak. Misalnya, namanya Hatija, maka sapaan gelarnya Umi Hatija; namanya Kalisum, maka sapaan gelarnya Umi Kaliso.

\section{c. Sapaan berupa gelar khusus dengan nama diri + kata sifat}

Dalam masyarakat Bima menyapa seseorang dengan keadaan lahiriah yang melekat pada dirinya merupakan hal yang biasa dan bukan merupakan ejekan atau cemoohan. Seseorang yang disapa sesuai dengan keadaan/sifat atau bentuk-bentuk badannya akan menerima sebagai sesuatu yang wajar. Misalnya, seseorang yang berperawakan pendek disapa poro, gemuk disapa mpore. Demikian juga seseorang yang bentuk badannya bungkuk disapa mbuku, pincang disapa mpeja. Seseorang yang kulitnya hitam atau putih disapa me'e atau bura. Sapaan gelar seperti itu dalam penggunaannya selalu diikuti atau didahului nama diri.

Contoh :

$\begin{array}{ll}\text { Nama diri } & +\quad \text { Sifat/keadaan } \\ \text { Kari } & \begin{array}{l}\text { poro 'pendek' } \\ \text { mpore 'gemuk' }\end{array}\end{array}$

Jenis Sapaan Kari poro 'Karim pendek' Sudi mpore 'Syamsuddin gemuk' 


$\begin{array}{lll}\text { Hama } & \text { mbuku 'bungkuk' } & \text { Hama mbuku 'Achmad Bungkuk' } \\ \text { Dahla } & \text { mpeja 'pincang' } & \text { Dahla mpeja 'Dahlan pincang' } \\ \text { Yunu } & \text { me'e 'hitam' } & \text { Yunu me'e 'Yunus hitam' } \\ \text { Maria } & \text { bura 'putih' } & \text { Maria bura 'Maria putih' }\end{array}$

Contoh penggunaan dalam kalimat :

- Hama mbuku wancuku cahana karawi. 'Achmad bungkuk sangat rajin bekerja'.

- Maria bura wa'u ra nika. 'Maria putih sudah kawin'.

\section{Simpulan}

Pola penggunaan sapaan bahasa Bima dan bentuk-bentuk sapaan yang umumnya digunakan oleh masyarakat penutur bahasa Bima sebagai berikut.

1) Sapaan berupa kata ganti diri (personal) yang terdiri atas persona pertama, kedua, dan ketiga, baik tunggal maupun jamak;

2) Sapaan berupa nama diri, yang terdiri atas sapaan nama diri yang sebenarnya dan nama diri bentuk penghormatan;

3) Sapaan berupa istilah keakrabatan;

4) Sapaan berupa nama jabatan dan gelar (gelar yang lazim dan gelar yang spesifik). Variasi pola penggunaan bentuk-bentuk sapaan tersebut di atas sangat ditentukan oleh faktor, antara lain usia/umur, status (stratafikasi) sosial, jenis kelamin, dan situasi penggunaan serta sifat-sifat tertentu yang melekat pada diri.

\section{Ucapan Terima Kasih}

\section{Daftar Pustaka}

Akhmad, dkk. (1989). "Struktur Bahasa Bima" (Laporan Penelitian) Yogyakarta: Tim Peneliti Departemen Bahasa dan Sastra Indonesia FKIP IKIP Yogyakarta.

Aminuddin. (1983). Bentuk Sapaan Bahasa Jawa Dialek Malang. Jakarta: Pusat Pembinaan dan Pengembangan Bahasa Departemen Pendidikan dan Kebudayaan RI.

Badudu, Rabiana. (1995). "Bentuk-bentuk Taksim di Dalam Referensi Pronomina Persona Bahasa-bahasa Gorontalo”. Disertasi Doktor Program Pascasarjana Universitas Hasanuddin Ujung Pandang.

Ayotrohaedi. (1980). Bentuk Hormat dalam Bahasa Sunda: Aspek Sosial Pengajaran Bahasa Asing di Indonesia (Seri Penerbitan Ilmiah). Jakarta: Fakultas Sastra Universitas Indonesia.

Gazalba, Sidi. (1962). Hubungan Bahasa-Sosial dan Kebudayaan dalam Kebudayaan sebagai Ilmu. Jakarta: Pustaka Antara.

Gusnawaty, G. (2013). "Pola Sapaan dalam Bahasa Bugis: Ritual Harmoni yang Merekatkan". Kongres Internasional Masyarakat Linguitik Indonesia (KIMLI).

Hasyim, M. (2008). "Faktor Penentu Penggunaan Bahasa Pada Masyarakat Tutur Makassar: Kajian Sosiolinguistik di Kabupaten Gowa". Humaniora.

Menjamin, S. (2018). "Bentuk Sapaan dalam Bahasa Melayu Dialek Satun, Thailand Selatan". MABASAN. https://doi.org/10.26499/mab.v11i1.52

Roselani, N. (1991). "Bentuk Sapaan dalam Bahasa Inggris dan Bahasa Indonesia". Jurnal Humaniora. 
Kamal, Mustapa, dkk. (1990). “Sistem Sapaan Bahasa Iban” (Laporan Penelitian). Jakarta: Pusat Pembinaan dan Pengembangan Bahasa Departemen Pendidikan dan Kebudayaan RI.

Kridalaksana, Harimurti. (1982). Dinamika Tutur Sapa dalam Bahasa Indonesia: Pelangi Bahasa. Jakarta : Bharata Karya Aksara.

Parera, Jos Daniel. (1991). Kajian Linguistik Umum Historis Komparatif dan Tipologi Struktural. Jakarta: Airlangga.

Sudaryanto. (1988). Metode Linguistik. Bagian Kedua: Aneka Metode Pengumpulam Data. Yogyakarta: Gadjah Mada University Press.

Supriyanto, Henricus, dkk. (1986). "Bentuk Sapaan Bahasa Jawa Dialek Jawa Timur" (Laporan penelitian), Jakarta: Pusat Pembinaan dan Pengembangan Bahasa Departemen Pendidikan dan Kebudayaan RI. 